\title{
VASPITNI STIL RODITELJA KAO FAKTOR OPŠTEG USPEHA UČENIKA
}

\author{
Apstrakt
}

U radu se razmatra povezanost, odnosno uticaj vaspitnog stila roditelja i uspeha učenika u školi, što ujedno predstavlja i cilj našeg istraživanja. Kao teorijsko polazište navode se modeli vaspitnog stila Šefera i Bomrajndove, a prikazani su i rezultati ranijih istraživanja ovog problema.

Rezultati našeg istraživanja su pokazali da je na prvom mestu po proceni ispitanika demokratski odnosno autoritativni vaspitni stil roditelja, na drugom izbegavajući odnosno indiferentni, na trećem mestu je autoritarni vaspitni stil, a na poslednjem mestu je popustljivi ili permisivan vaspitni stil roditelja, što ukazuje na izvesnu nedoslednost u vaspitnim postupcima, jer su sva četiri vaspitna stila vrlo ravnomerno distribuirana. Postoje izvesne razlike u distribuciji vaspitnih stilova roditelja od strane devojčica i dečaka u odnosu na autoritativni, indiferentni i permisivni vaspitni stil, kao i izvesno slaganje oba pola po pitanju procene autoritativnog vaspitnog stila roditelja.

Utvrđeno je da postoji pozitivna, statistički značajna korelacija između autoritativnog vaspitnog stila roditelja i školskog uspeha, kao i negativna statistički značajna korelacija između indiferentnog vaspitnog stila roditelja i školskog uspeha učenika. Između autoritarnog i permisivnog vaspitnog stila $i$ školskog uspeha postoji negativna korealacija koja se ovim istraživanjem i na ovom uzorku nije pokazala kao statički značajna.

Možemo da zaključimo da postoji uticaj vaspitnih stilova roditelja na školski uspeh učenika, što ukazuje na izvesne pedagoške implikacije koje za cilj imaju jačanje vaspitne funkcije škole i porodice i uspostavljanje advekvatne saradnje i partnerskih odnosa.

Ključne reči: vaspitni stil roditelja, porodica kao faktor uspeha učenika, školski uspeh

\section{Uvod}

$\mathrm{Na}$ formiranje identiteta deteta i njegov razvoj ličnosti utiču vaspitni postupci roditelja i njihovo celokupno ponašanje u procesu odrastanja deteta. Fenomen rodi-

\footnotetext{
11peldraga76@gmail.com
} 
teljstva je složen, veoma širok i kontinuiran proces koji je u značajnoj meri uslovljen karakteristikama različitih faza životnog ciklusa porodice, pri čemu se od roditelja očekuje da prilagodi svoje vaspitno delovanje specifičnostima svake faze (Zuković, 2012).

Zato možemo da kažemo da je vaspitanje deteta pre svega psihološko - emocionalno-bihejvioralna veština, a roditeljstvo jedna izuzetno složena uloga. Osim krajnosti, koje čine previše strogi i previše popustljivi roditelji, gde ne postoji savršen roditelj, nalazi se zlatna sredina koju predstavljaju majke i očevi koji svojoj deci obezbeđuju puno ljubavi, podrške i davanja jasnih smernica. Deca od roditelja ne primaju samo ljubav i nežnost, već i pogled na svet, način života, odnos prema društvu i odnos prema obavezama. Neposredan uticaj na vršenje roditeljske uloge imaju kako ličnost roditelja, tako i okolina. Ličnost roditelja uslovljena je genetikom, iskustvima iz detinjstva, odrastanjem i uticajem spoljašnje sredine. Poslednjih godina porodica prolazi kroz brojne radikalne promene u društvu. Vaspitni postupci roditelja značajno zavise od tih promena i na taj način utiču na razvoj deteta.

Pristupi su individualni i variraju u različitim kulturama. Roditelji žele da obezbede deci najbolje uslove za školovanje, udoban dom, posao nakon završetka školovanja, uspeh u sportu kojim se bave, savršeno detinjstvo, ne ostavljajući prostor da dete napravi grešku iz koje treba da nauči. Ovakvim prezaštitničkim ponašanjem današnji roditelji mogu potpuno da negiraju stvarnost u kojoj žive, jer pokušavaju da je kontrolišu prilagođavajući je potrebama svog deteta.

Zato je roditeljska uloga vrlo kompleksa. Kvalitetan odnos između roditelja i dece zavisi od brojnih parametara i kvalitativno se menja sa uzrasnim periodom deteta, jer se roditelji susreću sa značajnim zadacima i izazovima u pojedinim periodima razvoja svog deteta.

Da li porodica utiče na uspeh učenika i njegova školska postignuća? Ovo je tema je brojnih istraživanja. Mi ćemo se u ovom radu baviti proučavanjem vaspitnih stilova roditelja, koji su samo jedan, od brojnih faktora koji utiču na školski uspeh učenika. Ono što je važno za vaspitnu praksu jesu karakteristike pojedinih vaspitnih stilova koji se ogledaju kroz pojedine tipove roditelja i način njihove saradnje sa školom. Škola kao institucija trebalo bi da pruži informacije roditeljima o efektima pojedinih vaspitnih stilova i njihovim uticajem na uspeh učenika i da razvije strategiju saradnje u odnosu na pojedine tipove roditelja i njihove vaspitne stilove. Aktivno učešće i prisustvo roditelja u školi treba da omogući praćenje i kontrolu ponašanja deteta i da na taj način pozitivno utiče na školska postignuća, kao i da preduprede brojne aktuelne probleme dece u školskoj sredini. Iz svega navedenog proizilazi značaj ovog istraživanja kao i ove teme koja je samo jedan od segmenata uticaja, a koji se odnosi na kompleksnost i specifičnost problematike kako vaspitnih stilova roditelja tako i školskog uspeha učenika.

\section{Vaspitni stilovi roditelja}

U težnji da se ispita da li postoji uticaj različitih vaspitnih stilova roditelja na uspeh učenika u školi pošli smo od ispitivanja različitih teorijskih stavova koji opisuju 
prirodu vaspitnih stilova roditelja koji utiču na ponašanje deteta. U literaturi nailazimo na različite termine kojima se može opisati postupanje roditelja prema detetu: vaspitni stavovi, vaspitni stilovi, vaspitni postupci roditelja itd. U ovom radu biće korišćen termin vaspitni stilovi roditelja. Pod vaspitnim stilom roditelja u literaturi se podrazumeva realativno dosledan način ponašanja roditelja kojima se uspostavlja ukupan odnos sa detetom (Matejević, 2007). Vaspitni stil roditelja podrazumeva emocionalnu klimu unutar koje se odvija međudelovanje roditelj - dete (Čudina-Obradović i Obradović, 2002). Prihvaćeno je gledište da se vaspitni stilovi formiraju rano i da je reč o dvosmernom procesu, tj. dete usvaja model roditeljskog ponašanja, a reakciju deteta roditelj doživljava kao pozitivno ili negativno potkrepljenje za svoje postupke. Roditeljsko ponašanje, stavovi, vrednosti kreiraju vaspitne stilove roditelja čiji oblici zavise od nivoa izraženosti afektivne dimenzije i dimenzije kontrole. Iako su kod nekih stručnjaka u ovoj oblasti prisutne terminološke razlike model roditeljstva se opisuje preko ove dve bipolarne dimenzije. $\mathrm{U}$ radu se razmatra problem vaspitnog stila roditelja $u$ odnosu na afektivnu dimenziju i dimenziju kontrole, a kao teorijsko polazište navode se modeli vaspitnog stila Šefera i Bomrajndove .

Najuticajnijim se pokazao Šaeferov model (Schaefer, 1959, prema Piorkowska-Petrović, 1991, Matejević, 2007), koji pretpostavlja postojanje dve dimenzije: afektivnu dimenziju i kontrolu. Afektivna dimenzija predstavlja emocionalni odnos roditelja prema detetu i ima dva ekstrema: toplo i hladno vaspitanje. Dimenzija kontrole pokazuje dozvoljenu psihičku i fizičku slobodu i samostalnost deteta, a njeni polovi su popustljivo i ograničavajuće vaspitanje (Schaefer, 1959, prema Piorkowska-Petrović, 1991, Matejević, 2007). Kombinacijom ovih ekstremnih tačaka ili polova dveju dimenzija dobijaju se četiri različita vaspitna stava: toplo- popustljiv, hladno-popustljiv, toplo-ograničavajući i hladno-ograničavajući vaspitni stav. Roditelj čiji je vaspitni stav dominantno hladno- popustljiv emotivno je blizak sa svojim detetom pokazuje prihvatanje i pozitivne emocije. Dete je u takvoj atmosferi sigurno u roditeljsku ljubav i podršku, ali nije prezaštićeno. U kombinaciji sa toplim vaaspitanjem, popustljivost ne mora da znači nepostojanje pravila, već njihovo prilagođavanje ličnostima i potrebama deteta (Kodžopeljić 2009). Što je dete starije to mu se dopušta veća sloboda, a ono se više osamostaljuje. Za roditelje koje karakteriše hladno- popustljiv vaspitni stav u odnosu na decu kaže se da ne postoji opšta briga o deci, prema detetu, a roditelji se ponašaju hladno i odbojno i ne izlaze u susret potrebama deteta (Matejević, 2007). Popustljivost $u$ kombinaciji sa hladnoćom govori o odsustvu jasnih pravila ponašanja. Hladno - ograničavajući vaspitni stav roditelja odlikuje se retko ispoljavanju ljubavi roditelja prema detetu. $U$ tom slučaju fizička i psihička sloboda je potpuno kod deteta sputana (Matejević, 2007).

Diana Baumrind je 1967. godine izvršila reviziju Šaferovog (Schafer, 1959, prema Čudina-Obradović i Obradović, 2006) dvodimenzionalnog modela, zastupajući stav da je roditeljski nadzor (kontrola) najvažniji element roditeljske funkcije. Ona razlikuje tri osnovna stila roditeljstva: autoritarni, autoritativni (demokratski) i permisivni (laissez-fair). Autoritarni vaspitni stil podrazumeva visoko izraženu kontrolu od strane roditelja, njihovo strogo i nadmoćno ponašanje, dok se od dece očekuje poslušnost. Roditelj 
vidi poslušnost kao vrlinu i preferira kažnjavajuće, nasilne mere da bi zauzdao samovolju deteta, kada se detetove akcije ili verovanja ne podudaraju sa onim što on misli da je ispravno ponašanje. Ovaj model odgovara hladno - ograničavajućem vaspitnom stavu iz Šaferovog modela (Opsenica-Kostić, 2012). Autoritativni roditelji postavljaju zahteve i jasna pravila ponašanja, objašnjavajući pri tome deci razloge primenjivanja tih pravila. Iako je roditeljski autoritet zadržan, atmosfera u porodici je emocionalno topla i demokratska i dete zadržava osećanje pripadnosti i uvažavanja od strane roditelja što odgovara Šaferovom toplo-ograničavajućem vaspitanju. Permisivni roditeljski stav podrazumeva topao emocionalni odnos prema deci, ali nedostaju definisana pravila ponašanja. Permisivan roditelj preterano ugađa sopstvenoj deci i nije u stanju da održi kontrolu nad njihovim ponašanjem. Ovakav odnos roditelja i dece odgovara toplo-popustljivom vaspitnom stavu iz Šaferovog modela. Kasnije je Baumrindova u svoj model vaspitnih stavova uključila i indeferentni stav, koji podrazumeva potpunu nebrigu o detetu. Dete je prepušteno samom sebi, jer mu nedostaju i pravila i toplina porodičnog doma. Prisutno je emocionalno zanemarivanje deteta kao posledica toga što su jedan (ili oba) roditelja često odsutni od kuće ili preokupirani nečim drugim - radom, siromaštvom, sticanjem dobara, alkoholizmom, razvodom ili bolešću (Opsenica-Kostić, 2012). Ovaj model odgovara Šaferovom hladno-popustljivom vaspitnom stavu.

I u radovima autora s našeg područja (Genc i Kodžopeljić, 1995; Čudina-Obradović i Obradović, 2002; Kodžopeljići sar., 2008; Lacković-Grgin, 2006; Ljubetić, 2007; Petani, 2011) prevladava dvodimenzionalno posmatranje vaspitnog stila, te se u zavisnosti od nivoa izraženosti afektivne dimenzije i dimenzije kontrole, najčešće navode četiri vaspitna stila: autoritarni, permisivan, autoritativan i indiferentan (Zuković, 2015).

„Autoritaran vaspitni stil ogleda se u zahtevnom i restriktivnom ponašanju roditelja koji visoko vrednuju disciplinu i konformiranje s njihovim vrednostima, a ne pokazuju mnogo ljubavi i topline. Permisivan vaspitni stil opisuje se kao nerestriktivan, topao i prihvatajući, ali ne podrazumeva postavljanje jasnih granica u vaspitanju. Autoritativan vaspitni stil predstavlja kombinaciju između prva dva ekstrema i uključuje ponašanje roditelja koje je restriktivno i odgovorno, ali uz mnogo topline i razumevanja. Indiferentni vaspitni stil ogleda se u postavljanju malo ograničenja, ali i pružanju malo pažnje, zanimanja i emocionalne podrške od strane roditelja"( Zuković, 2015: 229). Vaspitni stilovi roditelja su pod uticajem brojnih faktora koji su u vezi sa roditeljima i decom, kao i užem i širem socijalnom, kulturno- religijskom kontekstu u kome porodica egzistira. Velike razlike među roditeljima i njihovim vaspitnom praksom postoje i unutar jedne kulturne grupe (Ljubetić, 2007). Postoje i ograničenja u području istraživanja koja su u vezi sa grupisanjem rezultata oko srednje vrednosti, tako da mali broj roditelja je ekstremno hladan- topao, tj. permisivan - kontrolišući (prema Zuković, 2015).

U svakom slučaju, činjenica je da različiti vaspitni stilovi roditelja podrazumevaju primenu različitih vaspitnih postupaka koji oblikuju ponašanje roditelja prema deci. Taj spektar roditeljskih postupaka i opšta emocionalna atmosfera u kojoj dete odrasta utiču na razvoj ličnosti i formiranje identiteta (Crnjaković i sar., 2008). 
Jasno je da se kod svakog roditelja prepliću ovi vaspitni stilovi i da priroda situacije često određuje kako će neko reagovati na nju. Ipak, praksa pokazuje da jedan stil preovlađuje i određuje odnos i ponašanje prema detetu. Prepoznavanjem i poznavanjem dominantnog stila, roditelj stiče polazište da sa određenim veštinama nastavi, da ih u izvesnoj meri prilagodi, ili da čak usvoji neke nove kojima će svoje roditeljstvo učiniti kvalitetnijim.

$\mathrm{Na}$ osnovu ovih teorijskih polazišta definisana su četiri vaspitna stila roditelja (autoritativni, autoritarni, permisivni i indiferentni) koji će biti predmet našeg istraživanja i koji će se posmatrati kroz prisustvo niske i visoke afektivne dimenzije i dimenzije kontrole.

\section{Porodica kao faktor uspeha/neuspeha učenika u školi}

Postoje brojna teorijska i empirijska istraživanja koja za svoj predmet imaju školski uspeh/neuspeh učenika. U istraživanjima o karakteristikama školskog neuspeha ukazuje se na brojne čionioce koji utiču na uspeh učenika u školi odnosno na njegovo školsko postignuće.

Faktori koji deluju na školski uspeh, tj. neuspeh, klasifikovani su u tri grupe (prema Krneta, 2000):

1. faktori koji proizilaze iz delovanja šire i/ili uže socijalne sredine na pojedinca;

2. faktori koji proizilaze iz ličnih karakteristika nastavnika kao ocenjivača i

3. faktori koji proizilaze iz osobina učenika.

Pregledom literature iz ove oblasti nalazimo da se razlike u neuspešnosti učenika u školi vezuju za veliki broj faktora. Najčešće su predmet analize prilike u porodici, situacije u školi ili karakteristike učenika.

Složenost pojave nameće potrebu za interdiciplinarnim pristupom u izučavanju ovog problema. Može se konstatovati da iako raširen problem, o školskom neuspehu se piše i istražuje i u okviru drugih tema i sa različitih aspekata (Maksimović, 2012).

Zorman je jedan od prvih autora koji je u svom istraživanju napravio korelaciju između porodice i školskog uspeha, odnosno istraživao je uticaj porodice na uspeh učenika u školi. Došao je do zaključka da su uspešniji učenici oni čiji su roditelji višeg obrazovnog nivoa u odnosu na učenike čiji su roditelji sa nižim obrazovanjem i kvalifikacijama. Danas je ta međuzavisnost manje izražena jer porodično okruženje danas nije jedini izvor obrazovanja za decu (prema Zorman, 1966).

Postoje i istraživanja (Troj, F. i saradnici 1967) koja ukazuju na relevantne faktore koji utiču na uspeh $\mathrm{tj}$. neuspeh učenika u školi. Tako kulturno - pedagoški nivo porodice u većoj meri utiče na uspeh odnosno neuspeh učenika, a u manjoj meri materijalni uslovi porodice. Faktori koji su pokazali da postoji značajna korelacija sa uspehom učenika su: nadzor nad radom učenika posle škole, odnosi u porodici, pol učenika, školska sprema roditelja, materijalne prilike i na kraju zaposlenost roditelja. Zaključak pomenutog istraživanja svedoči o činjenici da istaknuti faktori nisu jedini i 
presudni za postizanje uspeha, odnosno neuspeha učenika (prema Troj, F. i saradnici 1967).

U navedenim istraživanjima porodica je jedna od značajnih kategorija uzročnosti odnosno značajan faktor koji utiče na uspeh, tj. neuspeh učenika u školi. Otuda i težnja ka traženju korelacije između nekih relevantnih merljivih faktora porodice i uspeha učenika.

U studiji Krnete, Potkonjaka i Đorđevića o istraživanju neuspeha učenika u srednjim i osnovnim školama Beograda potvrđeno je da porodica vrši znatan uticaj na uspeh učenika. Takođe je pokazano da je uticaj slabiji kod starijih učenika, jer nisu potvrđene pretpostavke da su uzroci neuspeha porodični uslovi. Većina učenika koji su pokazivali neuspeh u toku školovanja žive u povoljnim porodičnim uslovima. Pošto je nemoguće ujednačiti kulturni nivo porodica, ostaje mogućnost da se utiče na faktore van porodice (prema Krneta, LJ. Potkonjak, N. i Đorđević, J. 1973).

Pored navedenih istraživanja koji su za predmet imali uticaj porodice na uspeh učenika, istraživanje koje su sprovele Matejević i Stojković, 2015. direktno dovodi u vezu uspeh učenika i vaspitne stilove roditelja. Cilj ovog istraživanja je da se utvrdi povezanost između vaspitnog stila roditelja i uspeha mlađih adolescenata u školi. Rezultati istraživanja su pokazali da je na prvom mestu permisivni vaspitni stil u kombinaciji sa toplim vaspitanjem, na drugom autoritarni vaspitni stil sa toplim vaspitanjem i na trećem mestu je demokratski, odnosno autoritativni vaspitni stil. Takođe je utvrđeno da postoji pozitivna, statistički značajna korelacija između demokratskog odnosno autoritativnog vaspitnog stila roditelja i školskog uspeha adolescenata, kao i negativna, statistički značajna korelacija između liberalno hladnog, odnosno zanemarujućeg vaspitnog stila roditelja i školskog uspeha adolescenata i autoritarno hladnog, odnosno odbacujućeg vaspitnog stila roditelja i uspeha učenika.

\section{Metod}

Ciljevi i hipoteze istraživanja. Osnovni cilj našeg istraživanja odnosi se na utvrđivanje povezanosti između vaspitnog stila roditelja i uspeha učenika u školi. Iako postoje istraživanja koja su se bavila ovom temom, ovo istraživanje treba da pokaže na našem uzorku, u našoj sredini, da li postoje razlike u odnosu na prethodno sprovedena istraživanja. Pored opšteg cilja treba da se utvrdi i dominantni vaspitni stil roditelja na osnovu opažanja ispitanika i da se utvrdi stepen zastupljenosti pojedinih vaspitnih stilova u zavisnosti od pola ispitanika.

$\mathrm{Na}$ osnovu teorijskih razmatranja, pomenutih istraživanja u ovoj oblasti i na osnovu ovako formulisanog cilja očekuje se da postoji značajna statistička povezanost vaspitnih stilova roditelja i uspeha učenika, što predstavlja opštu hipotezu istraživanja. Posebne hipoteze istraživanja odnosile su se na povezanost između demokratskog odnosno autoritativnog vaspitnog stila i boljeg uspeha učenika kao i postojanje negativne povezanosti permisivnog i indiferentnog vaspitnog stila sa slabijim uspehom učenika u školi. Očekuje se da je dominatni vaspitni stil i oca i majke demokratski i da postoji razlika u proceni vaspitnih stilova u odnosu na pol ispitanika tj. da u odnosu na devoj- 
čice i dečake postoji različita zastupljenost vaspitnih stilova roditelja. U istraživanju se kao nezavisna varijabla tretira vaspitni stil roditelja, a kao zavisna varijabla uspeh učenika u školi.

Uzorak istraživanja. Istraživanje je sprovedeno na prigodnom uzorku od 106 učenika sedmog razreda Osnovne škole „Đura Jakšić“ iz Kaća. Od ukupnog uzorka ispitanika 51 ispitanik je muškog, a 55 je ženkog pola. Kao prigodan uzorak izabrani su učenici sedmog razreda zbog specifičnosti uzrasnog perioda. Smatra se da u odnosu na uzrasni period imaju veći nivo zrelosti i ozbiljnosti u pristupu istraživanju. Ovaj period ogleda se i u kvalitetnijem odnosu roditelj- dete, što po našem mišljenju uzorak čini adekvatnijim u odnosu na ostale uzrasne kategorije učenika u osnovnoj školi. U pogledu obrazovnog nivoa roditelja $17,9 \%$ majki su fakultetski obrazovane. Visoko obrazovanje ima 10,4 \% očeva. Višu školu je završilo $19,8 \%$ majki i 18,9\% očeva, dok srednju školu ima najveći procenat roditelja i to majki 58,5\%, a očeva $65,1 \%$. Kao najniži stepen obrazovanja, odnosno završenu osnovnu školu ima 2, 8\% majki i 4,7\% očeva. Nasuprot tome magistarske ili doktorske studije ima $0,9 \%$ majki i $0,9 \%$ očeva.

Uspeh učenika je prikazan u Tabeli 1. i odnosi se na opšti uspeh koji su učenici imali na kraju šestog razreda. Od ukupnog broja učenika koji su učestvovali u istraživanju odličnih učenika ima najviše $43,4 \%$, vrlo dobrih $22,6 \%$, dobrih $32,1 \%$, dovoljnih $1,9 \%$, dok učenika sa nedovoljnim uspehom na kraju šestog razreda nema.

Tabela 1.

Opšti uspeh učenika

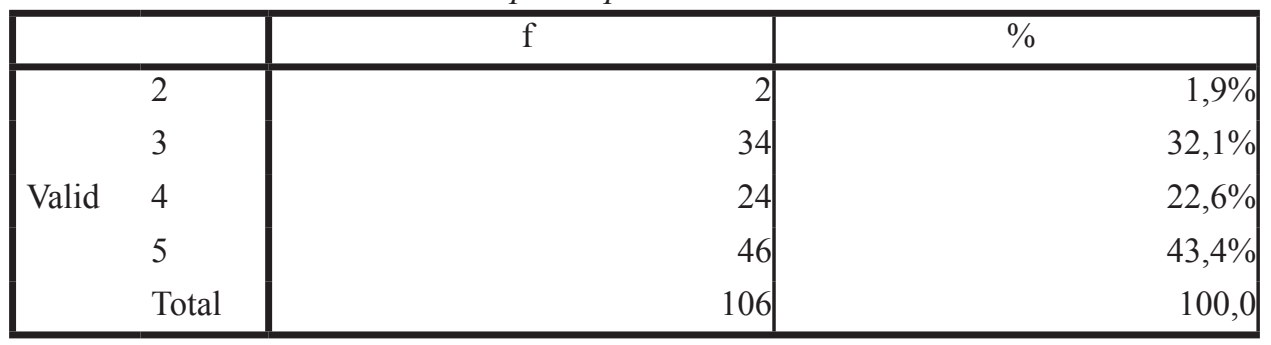

Instrumenti istraživanja. Za utvrđivanje vaspitnog stila roditelja, a na osnovu postavljenog cilja i hipoteza istraživanja instrument koji je korišćen je upitnik sa skalom Likertovog tipa. Skala je petostepena i izražava stepen slaganja sa tvrdnjom koja se izražava ocenama od 1 do 5 .

Svaka tvrdnja sadrži opis ponašanja roditelja, te se od ispitanika traži da na skali procene koliko je to ponašanje karakteristično za njegovog oca i majku, odnosno predstavlja percepciju vaspitnog stila roditelja iz perspektive deteta. S obzirom na to da se upitnik prvi put koristio u ovoj formi proverena je njegova pouzdanost primenom postupka za testiranje unutrašnje koenzistentnosti svake subskale upitnika. Visina dobijenih $\alpha$ Cronbach koeficijenta pouzdanosti ukazuje da upitnik ima zadovoljavajuću pouzdanost i da mogu da posluže za procenu vaspitnih stilova roditelja u istaživačke svrhe. Subskala koja odražava demokratski stil i emocionalnu toplinu roditelja sadrži 
5 tvrdnji (npr. „Roditelji poštuju moje mišljenje i ohrabruju me da ga iznosim”. Njena pouzdanost $\mathrm{u}$ ovom istraživanju iznosila je $\alpha=.73$ ). Subskala za autoritarni vaspitni stil i izraženu roditeljsku kontrolu sastoji se od 5 tvrdnji (npr. „Kad ne uradim nešto dobro roditelji me kazne", njena pouzdanost iznosila je $\alpha=.76$ ). Permisivni vaspitni stil određen je sa 5 tvrdnji koji karakteriše preterani zaštitničko i popustljivo ponašanje roditelja (npr. „Moji roditelji su popustljivi prema meni. ”). Dobijena pouzdanost ove subskale na testu je $\alpha=.82$. Subskala koja određuje indiferentni odnosno izbegavajući vaspitni stil ima takođe 5 tvrdnji i jedna od njih je (npr. „Roditelji nemaju vremena za mene i ne postavljaju mi nikakve zahteve"), a pouzdanost ove skale iznosi $\alpha=.84$.

Putem upitnika prikupljeni su i podaci o socio- demografskim karakteristikama: polu ispitanika, nivou obrazovanja roditelja i uspehu učenika.

Statistička obrada podataka. U istraživanju je korišćena deskriptivna metoda kojom je opisan uzorak kao i statistička metoda kojom su utvrđene statistički značajne povezanosti između ispitivanih pojava. U okviru obrade podataka izračunati su osnovni deskriptivni statistički parametri (prosečne vrednosti, frekvencije, standardna devijacija). Kao koeficijent korelacije prilikom analize podataka korišćen je Spirmanov koeficijent korelacije kojim se utvrđivala statistička povezanost između pojedinih vaspitnih stilova i uspeha učenika. Testom $\alpha$ Cronbach koeficijenta se procenjivalo pouzdanost tvrdnji u upitniku, analizom varijante postojanje statičke povezanosti između grupa ispitanika, odnosno razlike u procenjivanju vaspitnih stilova roditelja od strane dečaka i devojčica dobijeni su Scheffe-ov Post hoc test. Program koji je korišćen u istraživanju je SPSS statistica.

\section{Analiza i rezultati istraživanja}

Dobijeni rezultati podeljeni su u tri grupe i predstavljaju odgovore na postavljene hipoteze istraživanja i realizovane ciljeve. U prvoj grupi su rezultati koji pokazuju distribuciju vaspitnog stila roditelja dobijeni na osnovu procene od strane naših ispitanika. Aritmetičkom sredinom dobijena je srednja ocena za svaki vaspitni stil pojedinačno, a veća srednja ocena ukazuje na veću zastupljenost pojedinog vaspitnog stila roditelja u odnosu na drugi, odnosno dominantan vaspitni stil roditelja (majke i oca). Drugu grupu podataka čine podaci vezani za rezultate dobijene ocenjivanjem tvrdnji koje opisuju vaspitne stilove roditelja, a procenjeni su u odnosu na pol ispitanika. U trećoj grupi su prikazani rezultati koji pokazuju korelaciju, odnosno postojanje statističke povezanosti između vaspitnih stilova roditelja i uspeha učenika u školi. Iako nije moguće generalizovati na nivou ovog uzorka i načina obrade podataka, ovi rezultati su značajni kao pokazatelji procene zastupljenosti vaspitnih stilova na ovom uzorku i ukazuju na značajnu statističku povezanost, odnosno korelaciju sa školskim uspehom.

Distribucija vaspitnog stila roditelja. Razlike u opažanju roditeljskih vaspitnih stilova, prikazani su u Tabeli 2. i ukazuju na zastupljenost pojedinih vaspitnih stilova roditelja na osnovu procene ispitanika. Najdominantniji vaspitni stil rodite- 
lja je demokratski vaspitni stil ima srednju ocenu (AS=3.77). Na drugom mestu je indiferentni vaspitni stil roditelja, na trećem autoritarni, a na poslednjem mestu po proceni ispitanika je permisivni vaspitni stil roditelja. Ukoliko posmatramo rezultate, odnosno srednje ocene za vaspitne stilove majke i oca, možemo da konstatujemo da nema razlika u proceni od strane ispitanika. Demokratski stil je po našim rezultatima najzastupljeniji što potvrđuje našu hipotezu i očekivanja u vaspitnoj praksi. Može se konstatovati da najveći broj roditelja kao dominantan vaspitni stil ima demokratski. Ove roditelje karakteriše visoka kontrola i visoko prihvatanje u vaspitnim postupcima sa svojom decom. Zabrinjavajući je podatak dobijen istraživanjem da je visoka zastupljenost indiferentnog vaspitnog stila roditelja čija srednja ocena iznosi (AS=3.20). Ispitanici su tvrdnje koje opisuju indiferentan stil roditelja visoko ocenili, što ukazuje na zaključak da su roditelji ispitanika u većoj meri odsutni, prezaposleni, ne bave se dovoljno svojom decom, nisu u dovoljnoj meri uključeni niti zainteresovani za njih. Ovo su samo neke od karakteristika ovog vaspitnog stila koje karakteriše odsustvo kontrole i emocionalne podrške. Autoritarni vaspitni stil po proceni ispitanika nije visoko zastupljen i ima srednju ocenu ( $\mathrm{AS}=2.74)$. Podrazumeva visoko izraženu kontrolu od strane roditelja, njihovo strogo i nadmoćno ponašanje. Ovaj model odgovara hladno- ograničavajućem vaspitnom stavu iz Schaferovog modela. Poslednje mesto zauzimaju po proceni ispitanika, roditelji kojima je dominantan vaspitni stil permisivan sa srednjom ocenom ( $\mathrm{AS}=2.55$ ), odnosno popustljiv vaspitni. Ovaj vaspitni stil roditelja karakteriše toplo- popustljiv vaspitni stav. Ovakvi roditelji preterano popuštaju svojoj deci i nisu u stanju da održe kontrolu nad njihovim ponašanja

Tabela 2.

Distribucija vaspitnog stila roditelja

\begin{tabular}{|c|c|c|c|}
\hline Vaspitni stilovi roditelja & \multicolumn{3}{|c|}{$\begin{array}{l}\text { ARITMETIČKA SREDINA(AS) } \\
\text { (srednja ocena) } \\
\text { majka otac roditelji }\end{array}$} \\
\hline Demokratski vaspitni stil & 3,86 & 3,68 & 3,77 \\
\hline Autoritarni vaspitni stil & 2,84 & 2,64 & 2,74 \\
\hline Permisivni vaspitni stil & 2,54 & 2,55 & 2,55 \\
\hline Indiferentni vaspitni stil & 3,32 & 3,09 & 3,20 \\
\hline
\end{tabular}

Razlike u proceni zastupljenosti vaspitnih stilova roditelja u odnosu na pol ispitanika. Kako bismo utvrdili da li postoji statistički značajna razlika, u procenu vaspitnih stilova u odnosu na pol ispitanika, uradili smo analizu varijanse da utvrdimo postojanje statičke povezanosti između grupa ispitanika, a razliku u procenjivanju vaspitnih stilova u odnosu na pol ispitanika utvrdili smo pomoću Scheffe-ov Post hoc testa. Utvrđena je statistički značajna razlika u pogledu opažanja vaspitnih stilova roditelja u odnosu na pol ispitanika. U tabeli 3 prikazana je statistički značajna razlika 
(po Scheffe-ov Post hoc testa nivou značajnosti $(p<0.01)$ u proceni vaspitnih stilova roditelja u odnosu na pol. Rezultati pokazuju da jedino kada je u pitanju demokratski stil vaspitanja nisu ustanovljene značajne razlike u procenjivanju vaspitnih stilova roditelja s obzirom na pol ispitanika.

Tabela 3.

Razlika u proceni vaspitnih stilova u odnosu na pol ispitanika

\begin{tabular}{|c|c|c|c|c|c|}
\hline Vaspitni stil roditelja & $\begin{array}{l}\text { Sum of } \\
\text { Squares }\end{array}$ & $\mathrm{df}$ & $\begin{array}{l}\text { Mean } \\
\text { Square }\end{array}$ & $\mathrm{F}$ & Sig. \\
\hline Demokratski devojčice & ,041 & 1 & ,041 & ,072 & ,789 \\
\hline dečaci & 59,869 & 104 & .576 & & \\
\hline Total & 59,911 & 105 & & & \\
\hline Autoritarni devojčice & 5,910 & 1 & 5,910 & 5,291 & "023, \\
\hline dečaci & 116,158 & 104 & 1,117 & & \\
\hline Total & 122,067 & 105 & & 176 & $021 \%$ \\
\hline Permisivni devojčice & 4,045 & 1 & $4,04 \mathrm{~J}$ & 4,105 & "OS1, \\
\hline dečaci & 88,283 & 104 & 849 & & \\
\hline Total & 92,328 & 105 & 2003 & 4383 & $020 \%$ \\
\hline Indiferentni devojčice & 2,993 & 1 & 2,930 & & \\
\hline dečaci & 70,999 & 104 & 683 & & \\
\hline Total & 73,992 & 105 & & & \\
\hline
\end{tabular}

Napomena: na nivou značajnosti $* \mathrm{p}<0.01)$.

Povezanost vaspitnog stila roditelja i opšteg uspeha. Kada su u pitanju povezanost vaspitnog stila roditelja $i$ uspeh učenika, rezultati istraživanja su delimično potvrdili pretpostavku od koje smo pošli u istraživanju. Korelacije ispitanih varijabli prikazane su da je u Tabeli 4 . utvrđena statistički značajna pozitivna korelacija između autoritativnog tj. demokratskog vaspitnog stila roditelja i uspeha učenika, $\left(r_{S}=0,26\right.$, $\mathrm{p}<0.05$ ). Postoji i negativna statistički značajna korelacija između školskog uspeha $\mathrm{i}$ indiferentnog vaspitnog stila roditelja, $\left(r_{S}=-.027, \mathrm{p}<0.05\right)$. U odnosu na autoritarni i permisivni vaspitni stil istraživanjem nije dobijena statistički značajna korelacija sa opštim uspehom, sem da je korelacija između ova dva vaspitna stila negativna u odnosu na školski uspeh. To znači da postoji pozitivna korelacija između uspeha i demokratskog vaspitnog stila roditelja, što ukazuje da ovaj vaspitni stil roditelja utiče pozitivno na uspeh učenika. Roditelje kod kojih prevladava ovaj vaspitni stil karakteriše emocionalno topla atmofera, jasno postavljanje granica, doslednost u sprovođenju. To su roditelji koji imaju puno razumevanja za svoje dete i spremni su da ga saslušaju. Odnos roditelja i deteta karakteriše topao odnos pun ljubavi, podrške i uvažavanja. Na 
osnovu dobijenih rezultata može se zaključiti da ovaj vaspitni stil, tačnije demokratski vaspitni stil roditelja se pozitivno odražava na školski uspeh učenika. Suprotno od toga roditelji kod kojih je karakterističan indiferentni vaspitni stil nisu u dovoljnoj meri posvećeni i zainteresovani za svoju decu, pa ni za njihova školska postignuća. Postojanjem ovakve negativne korelacije dolazi se do zaključka da ovakav dominantan indiferentni vaspitni stil roditelja utiče negativno na uspeh učenika u školi.

Tabela 4.

Povezanost vaspitnog stila roditelja i školskog uspeha (Spirmanov koeficijent korelacije)

\begin{tabular}{|c|c|c|c|c|}
\hline \multicolumn{3}{|c|}{ Vaspitni stil i školski uspeh } & \multicolumn{2}{|c|}{$\begin{array}{c}\text { Spirmanov koeficijent } \\
\text { korelacije }\left(r_{S} .\right)\end{array}$} \\
\hline \multirow{6}{*}{ Spearman's rho } & & Correlation Coefficient & 1,000 & ,216* \\
\hline & uspeh & Sig. (2-tailed) & &, $026^{*}$ \\
\hline & & $\mathrm{N}$ & 106 & 106 \\
\hline & & Correlation Coefficient &, $216^{*}$ & 1,000 \\
\hline & Demokr. stil & Sig. (2-tailed) & ,026 & \\
\hline & & $\mathrm{N}$ & 106 & 106 \\
\hline \multirow{6}{*}{ Spearman's rho } & & Correlation Coefficient & 1,000 &,- 135 \\
\hline & uspeh & Sig. (2-tailed) & &, 167 \\
\hline & & $\mathrm{N}$ & 106 & 106 \\
\hline & & Correlation Coefficient &,- 135 & 1,000 \\
\hline & $\begin{array}{l}\text { Autoritarni. } \\
\text { stil }\end{array}$ & Sig. (2-tailed) & ,167 & \\
\hline & & $\mathrm{N}$ & 106 & 106 \\
\hline \multirow{6}{*}{ Spearman's rho } & & Correlation Coefficient & 1,000 &,- 018 \\
\hline & uspeh & Sig. (2-tailed) & & ,853 \\
\hline & & $\mathrm{N}$ & 106 & 106 \\
\hline & & Correlation Coefficient &,- 018 & 1,000 \\
\hline & Permisivni sti & Sig. (2-tailed) &, 853 & \\
\hline & & $\mathrm{N}$ & 106 & 106 \\
\hline
\end{tabular}




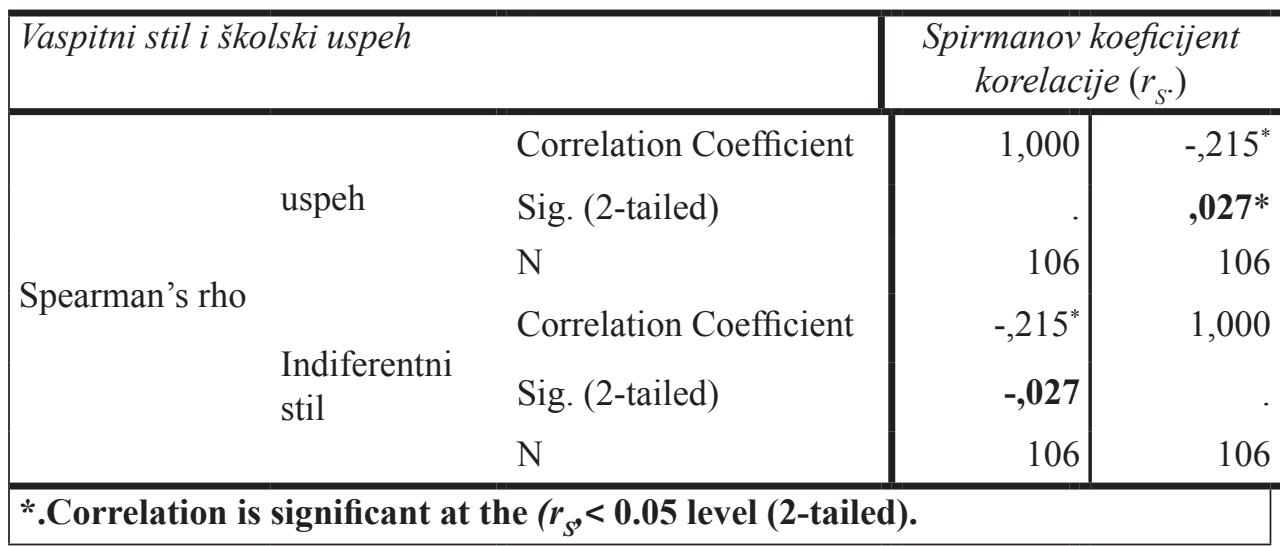

Napomena: Spirmnov koeficijent korelacije $\left(r_{s}\right)$, - je negativan smer korelacije.

\section{ZAKLJUČAK}

Rezultati istraživanja su pokazali da postoji statistički značajna korelacija između demokratskog, odnosno autoritativnog vaspitnog stila roditelja i uspeha učenika u školi, i negativne korelacije između indiferentnog vaspitnog stila roditelja i školskog uspeha. Dobijeni rezultati pokazuju, da ukoliko je u postupanjima roditelja indiferentan vaspitni stil izraženiji da je utoliko uspeh učenika lošiji, a ukoliko su postupanja roditelja u skladu sa demokratskim vaspitnim stilom, uspeh učenika u školi je bolji. Indiferentan vaspitni stil negativno utiče na dete što se odražava na njegova školska postignuća. Može se zaključiti da postoji uticaj pojedinih vaspitnih stilova roditelja na opšti uspeh učenika i da možemo govoriti o vaspitnim stilovima roditelja kao jednom od značajnih faktora koji utiču na opšti uspeh učenika u školi.

Škola kao vaspitno - obrazovna ustanova utiče na pozitivna postignuća svojih učenika i treba da pruža roditeljima relevantne informacije o efektima različitih vaspitnih stilova i na taj način pomogne roditeljima u pronalaženju adekvatnijih vaspitnih postupaka za svoju decu. Dobijeni rezultati ukazuju na potrebu organizovanja edukacije za roditelje i unapređenje saradnje između porodice i škole. Ukoliko odeljenjski starešina poznaje roditelje svojih učenika i uoči njihove vaspitne stilove u postupanju prema deci, može pojedinačno da razvija strategiju saradnje $u$ odnosu na pojedine tipove roditelja $i$ njihove dominantne stilove. Na taj način obostranim delovanjem škole i porodice mogu da se preduprede mogući problemi koji postoje u školskoj sredini i u ponašanju učenika.

Iako nedovoljna reprezentativnost uzorka uz to i kompleksnost samog problema istraživanja otežava generalizovanje rezultata, ipak je moguće konstatovati da ovaj nalaz istraživanja donekle ima svoj značaj koji može biti polazna osnova u unapređenju vaspitno - obrazovne prakse i pedagoškog delovanja u sredini u kojoj je istraživanje sprovedeno, a ujedno može da posluži kao poređenje sa drugim relevantnim empirijskim istraživanjima koji u svom predmetu istraživanja imaju vaspitne stilove roditelja i njihov uticaj na uspeh učenika u školi. 


\section{Literatura}

Baumrind, D. (1991). The influence of parenting style on adolescent competence and substance use. Journal of Early Adolescence, 11(1), 56-95.

Crnjaković, B., Stojiljković, S. i Todorović, J. (2008). Vaspitni stil roditelja i lokus kontrole adolescenata. Nastava i vaspitanje, 57(4), 514-529.

Čudina-Obradović, M., Obradović, J. (2002). Potpora roditeljstvu: izazovi i mogućnosti. Revija za socijalnu politiku, 10(1), 45-68.

Čudina-Obradović, M., Obradović, J. (2006). Psihologija braka i obitelji. Zagreb, Golden Marketing-Tehnička knjiga.

Genc, L. (1988). Dimenzije vaspitanja i razvoj ličnosti: teorija i istraživanja. Psihologija, 21, 121-132.

Kodžopeljić, J. (2009). Procena vaspitnih stavova (VS-skala). U M. Biro, S. Smederevac i Z. Novović (Ur. ), Procena psiholoških i psihopatoloških fenomena, Beograd, Centar za primenjenu psihologiju, 165-178.

Kodžopeljić, J., Pekić, J., Genc, A. (2008). Relacije između vaspitnih stavova roditelja i autoritarnosti dece. Pedagoška stvarnost, LIV, 9-10, 1027-1038

Krneta, LJ, Potkonjak, N. i Đorđević, J. (1973). Neuspeh učenika u osnovnim i srednjim školama Beograd, Beograd, str. 186

Krneta, LJ. (2000) Faktori školskog uspjeha, BanjaLuka, str. 21

Ljubetić, M. (2007). Biti kompetentan roditelj. Zagreb: „Mali profesor“

Matejević, M. (2007). Vrednosne orijentacije i vaspitni stil roditelja, Niš, Filozofski fakultet.

Matejević, M. i Todorović, J. (2012). Funkcionalnost porodičnih odnosa i kompetentno roditeljstvo. Niš, Filozofski fakultet.

Matejević, M. (2012). Funkcionalnost porodičnih sistema i vaspitni stil roditelja i obrasci komunikacije u porodicama sa adolescentima. Nastava $i$ vaspitanje, LXI, 1, 128-141.

Matejević, M. Stojković, J. (2012). Vaspitni stil roditelja i školski uspeh mlađih adolescenata, Inovacije u nastavi- časopis za savremenu nastavu Tradicija, modernizacija i nacionalni identitet u Srbiji i na Balkanu u procesu evropskih integracija, vol. 25 , br. 2 , str. $37-46$

Maksimović, J. (2012). Pregled metodologije istraživanja školskog neuspeha u značajnim studijama, Niš, Filozofski fakultet. 303-331.

Opsenica-Kostić, J. (2012). Adolescenti i njihovi roditelji u svetlu PART teorije (Nepublikovana doktorska disertacija). Univerzitet u Nišu, Filozofski fakultet.

Piorkowska-Petrović, K. (1991). Jedan model za ispitivanje vaspitnih stavova roditelja, Psihologija, 24, 1-2, 170-179.

Todorović, J. (2004). Vaspitni stilovi u porodici i stabilnost samopoštovanja adolescenata. Psihologija, 37, 183-194.

Todorović, J. (2005). Vaspitni stilovi roditelja i samopoštovanje adolescenata. Niš, Prosveta 
Troj, F. i saradnici (1967) Učešće nekih faktora u slabom uspehu učenika, Zbornik, br. 1, Institut za pedagoška istraživanja, Beograd, str. 227-256.

Zorman, L. (1966) Uticaj socijalno-ekonomskog statusa učenikove porodice naškolski uspeh i nastavak školovanja, Psihologija, broj 1, Beograd.

Zuković, S., Ninković, S., Krstić, K (2015). Vaspitni postupci roditelja iz ugla adolescenata, Psihološka istraživanja, 125-143.

Zuković, S. (2012). Porodica kao sistem - funkcionalnost i resursi osnaživanja. Novi Sad, Pedagoško društvo Vojvodine.

\title{
Dragana Pelegiš
}

Primary school "Đura Jakšić", Kać

\section{PARENTING STYLE AS A FACTOR OF STUDENTS OVERALL SUCCES}

\begin{abstract}
The article is considering the influence of parents' style of upringing children on students' success at school and their connection which is also the goal of our research. The theoretical basis of the research are Schaefer and Baumrind's models of the upbringing and the results of some previous researches as well.

The results of our research show that the first place, according to the judgement of the respondents, takes the democratic or authoritative style of the upringing. The second place takes the avoiding or indiferent style. The third place takes the authoritarian style and the last place takes the relenting or permissive one. This shows the obvious inconsistency in the process of upringing since all four upbinging styles are distributed equally. There are some differences between the distribution of the upbringing styles for girls and the ones for boys in regard to the authoritattive, indiferent and permissive style and the compatibility of the both genders according to the evaluation of the authoritative style.

It is determined the presence of positive, statistically significant corelation between the authoritative upbringing style og parents and students' success at school. There is a negative corelation between the authoritative and permissive upbringing style and students' success at school and according to this research and this sample proved to be statistically insignificant.

We can conclude that there is the presence of the infuelce of parents' style of upbringing children to students' success at school which indicates certain pedagogical implications whose aim is to improve the upbringing functions of school and family and to establish an adequate colaboration and associative relationships.
\end{abstract}

Key words: parents' upbringing style, family as the factor of students' success, success at school 